and the Secretary is now in diroct touch with a large number of timber users and research workers throughout the world.

\section{Psychology of Delinquency}

"Studies In the Psychology of Delinguency", by Grace W. Pailthorpe (Medical Research Council, Special Report Series. No. 170), represents the result of five years work on the psychology of inmates of prisons and of proventive and rescue homes. The investigation aims at finding out what troatment would lead to a restoration of theso peoplo to the ranks of the normal. It is necessary to note that a criminal is not necessarily quite different from other people; he has been found out. Dr. Pailthorpo gives details of an investigation of 200 subjects, 100 in prisons and 100 in homes. The subjects were tested for intelligence, and classified accordingly, as normal, sub-normal, and defective. The prison group proved to have a higher proportion of normals. It is not infrequently asserted that prison people are defective in intelligence: some certainly are, but some are not. They were also interviewed, and classified according to their emotional attitudes. This part of the report is excellent and the detailed case histories are very valuable. It seems obvious on reading them that our presont alternatives in dealing with criminals are hopelessly inadequate and wasteful of money as well as of the human material. A large number show clear signs of mental lack of balance, and it should be part of an enlightened society's work to try to find out the cause. Hence the writer makes a plea for a study of the mentality of the criminal as well as of the crime, and discusses various alternative methods of treatment, including segregation, permanent supervision, education and psychotherapy. Many of the prisoners are really mentally sick, and if there were legal recognition of these conditions some murders might be prevented. In an appendix there is an account of some prison systems abroad.

\section{Announcements}

Prof. J. A. Crowther, professor of physics in the University of Reading since 1924, has been elected honorary secretary of the Institute of Physics, in succession to Prof. A. O. Rankine.

Referring to Prof. P. G. H. Boswell's letter in Nature of August 13 on the subject of the age of the Oldoway skeleton, Dr. L. S. B. Leakey writes to say that he is returning to England at the end of December, and hopes then to be able to place the wholo evidence against Prof. Boswell's conclusions before scientific investigators.

THE first Hinchley Memorial Lecture of the Institution of Chemical Fingineers will be delivered at the Institution of Civil Engineers, Great George Street, Westminstor, S.W.1, by Mr. H. T. Tizard, on October 28, at 6.30 P.M. The subject of Mr. Tizard's lecturo will be "Chemical Engineering and the Aircraft Industry".

No. 3286, Vol. 130]
Tre Lord President of the Council has appointed Prof. A. Fowler and Sir Clement Hindley to be members of the Advisory Council to the Committee of the Privy Council for Scientific and Industrial Research in succession to Sir Alfred Ewing and Sir David Milne-Watson, who have retired on completion of their terms of office. The Lord President of tho Council has also appointed Brigadier-General Sir Harold Hartley to be chairman of the Fuel Research Board, and Dr. N. V. Sidgwick to be chairman of the Chemistry Research Board of the Department of Scientific and Industrial Research, in succession to the late Sir Richard Threlfall.

Tre eighth volume (Pt. 2, Science Section) of the Allahabad Univ. Studies (1932) contains half a dozen papers from the Department of Zoology, five from that of Chemistry and one each from the Depart. monts of Botany and Physics. In the first group it is natural that the work of the head of the department (Prof. Bhattacharya) should bo reflected in the investigations of his pupils and two of the papers are on the Golgi bodies and other cytoplasmic structures in the eggs of Indian snakes and of the crab, Scylla serrata. Other papers record the congenital absence of limbs in tortoises, the structure of the gonad in a hen-feathered cock, and a number of now species of trematodes. Of the chemical papors, that on the formation of inorganic jollies may be noted.

Messrs. Negretti and Zambra have placed on the market a portable sampling hygrometer adapted for the measurement of the hygrometric conditions inside bundles of fabric, wool, fibres, etc. The instrument is of the hair hygrometer type fitted with a tube through which a sample of air is withdrawn from the bundle and circulated through the hygrometer case, which is completely air-tight except for the inlet and outlet air connexions.

Applications are invited for the following appointments, on or before tho dates mentioned :--A research student in the Institute of Pathology and Research at St. Mary's Hospital, Paddington, W.2-The Secretary (Oct. 24). An assistant lecturer in mathematies at the Technical College, Cardiff-The Diroctor of Education, City Hall, Cardiff (Oct. 29). A junior lecturer in the Department of Pathology at the University of Liverpool-The Registrar (Oct. 31). An assistant lands officer in the Works and Juildings Directorate of the Air Ministry-The Secretary (S.2), Air Ministry, Adastral House, Kingsway, W.C.2 (Nov. 1). An assistant lecturer in metallurgy at the Cniversity of Leeds-Tho Registrar (Nov. 7). A part-time instructor of economics and economic history at the Kingston-upon-Thames Technical College-The Principal. A teacher of elementary science, including biology, and a mistress to. teach geography, at the Medway Technical College, Day Technical School for Girls, Chatham-The District Education Officer, 15, New Road Avenue, Chatham. A valve physicist and designer at the Murphy Radio Laboratories, Welwyn Garden City, Herts. 